\title{
LANGUAGE IMPOLITENESS IN JAKARTA LAWYERS CLUB TALK SHOW 2014 Meisa Fitri Nasution
}

Dosen Tetap Sekolah Tinggi Ilmu Ekonomi Labuhan Batu

\begin{abstract}
The objectives of this descriptive qualitative study were to discover: (1) the types of impoliteness strategy, (2) types of attacks, and (3) how the responses to the impolite attack in Jakarta Lawyers Club (JLC) Talk Show on TVOne. The source of data were the participants' utterances in JLC Talk Show from the topics of Talk Show namely Badai Demokrat Menerjang Kemana-Mana, Anas Siap Digantungdi Monas, and Dibalik Bungkamnya Nazaruddin in order to find out therecurrences and the pattern of the data based on the problem of the study. The data were identified, analyzed and categorized based on Culpeper's (1996) theory. The findings of the study shows that: 1) there were four types of impoliteness strategies appeared in JLC Talk Show, namely Bald On Record Impoliteness (37.5\%), Positive Impoliteness (27.5\%), Negative Impoliteness (25.0\%), and Sarcasm (10\%), 2) there were two types of attacks appeared in JLC Talk Show namely Attacks on Quality Face (92.5\%) and Attacks on Social Identity Face (7.5\%), and 3) in responding to the impolite attacks, there were three ways appeared in JLC Talk Show namely not responding (52.5\%), countering defensively (32.5\%), and countering offensively (15.0\%). The findings shows that JLC Talk Show was a formal context of Talk Show in which its participants were educated people who mostly use a direct strategy of impoliteness (Bald On Record Impoliteness) in attacking on the other participants' personal quality (Quality Face) but the attacks dominantly were not responded by them. Therefore, it can be concluded that in communication, everyone may convey his or her opinions, arguments, and feelings but he or she should express the good attitude to communicate. Some suggestions are directed to those who are interested in understanding impoliteness strategy as found in practice.
\end{abstract}

Keywords: Language, Impoliteness, Talk Show

\section{INTRODUCTION}

Communication through media is the communication delivered directly to the public. Sociocultural norms wants people to be polite in interacting with others. The important thing with regard to the success of social interaction through language settings are strategies that take into account the status of the speakers and partners have to say about the topics exposed. The successful use of these strategies is to create an atmosphere of social politeness that allowstransactions to take place without shaming speakers and speech partner (Ismari, 1995: 35).In particular, communication between host(s) and guest(s) on TV Talk Show is necessary because it affects both the guest's and the host's public image, job benefits, not only at the present time, but also in the future. In Talk Show on $\mathrm{TV}$, the participants are trying to keep the communication to run well and smooth. However, because of the difference of thoughts and interests in the interactive dialogue, it was found the 


\section{Jurnal Ecobisma Vol. 4 No. 2 Juni 2017}

implementation of impoliteness strategy as the attempt to attack the other participants in the Talk Show. Due to the nature of Talk Shows, the host of Jakarta Lawyers Club Talk Show pose sensitive

questions or the participants give answers which may cause the other participants' dissatisfaction, and may result in conflict among the participants and host, they become embrassed and then they become face lose.Impolite statements and personal attacks are two of the most

common causes of conflict escalation. When people attack other people verbally, those attacks are likely to get especially defensive or angry. When people are told that they are at fault for a particular situation, or that they are evil or stupid for believing something or advocating a particular action, the person attacked is likely to respond in a very negative way. They are much more likely to dig in their heels and stand firm, refusing to listen to the other side's arguments or consider making compromises or concessions. They will just reject the other side as unreasonable, and ignore anything they have to say. When situations are exaggerated or emotional, negative statements are made about the opponent for the purpose of arousing support for one's own cause, the result is likely to increase support for both sides. Those making the inflammatory statements will not only increase support for their own side but they are also likely to increase their opponent's support, as people who realize that the statements are an unfair exaggeration will side with the party being accused, rather than the accuser. The result will not be a change in the relative support of one's own group (or in one's power relative to the other side), but rather an overall escalation of the conflict, which will make it more difficult for both sides to get what they need.

The researcher of Indonesia Media Watch (IMW) states that Jakarta Lawyers Club (JLC) Talk Show often breaks the rules of broadcasting, especially human rights such as reported from setkab.go.id, the host didn't stop insulting the deed of a guest to the other guests with a call "short, like a guard of mosques, and others." In other case a lawyer and also a guest in the show commented, "It is evident, when he is poor, when he has not been able to post, he attacked the government so heavily...". As well as the lawyer's comment on the guest's personality when the guest struck an officer of a jail and then he only apologized. The lawyer said, "He was talking not using his brain". These types of violations are categorized as a violation of the protection of a person and / or community norms of decency. During an interview, especially one regarding a guest's personal experience, the host(s) and guest(s) should avoid the use of impoliteness strategies in order to avoid making the guest embarrassed or dissatisfied with or her questions and comments. According to the Broadcasting Law No. 32 in 2002 on Broadcasting, Article 36 paragraph 6 prohibits, "disparage, humiliate, harass and / or neglect the religious values, human dignity, or damage the international relations".

This phenomenon is necessary to be studied because the applications of impoliteness language cause offend and misunderstanding, conflicts and violence in personal life and even in society. A great number of conflicts and violence in society happened lately caused by blaspheming, disfiguring, and even abusing verbally among members of society became the indicators that the society has lost the magnificence of their life. Now, through the television program Indonesian society has the tendency to leave the society norms. Communicative strategies that are employed to promote and maintain 
social harmony have always been the focus of politeness theories or politeness phenomenon . Little research has been conducted in the field of impoliteness studies to examine communicative strategies with the opposite orientation, i.e. the communicative strategies that are used to disrupt

social harmony. In other words, linguistic means of attacking 'face' causing social conflict or disruption have not been given enough focus in research on impoliteness especially in discourse.

This present study aims at examining the model of 'impoliteness', as first proposed by Culpeper (1996) and as revised and developed later by Culpeper et al. (2003) and Culpeper (2005). In line with Culpeper's (1996) theory of impoliteness, the researcher is very much interested in conducting a study on types of impoliteness strategies occurred namely Bald on Record Impoliteness, Positive Impoliteness, Negative Impoliteness, Sarcasm and Withhold Politeness, types of attacks and how attacks are responded in Jakarta Lawyers Club (JLC) Talk Show on TVOne .

\subsection{The Problems of the Study}

The problems of the study are formulated as in the following. What are the types of impoliteness strategies expressed by the participants in Jakarta Lawyers Club Talk Show?

What types of attacks are appeared in Jakarta Lawyers Club Talk Show?

How are the attacks responded by the participants in Jakarta Lawyers Club Talk Show?

\subsection{The Objectives of the Study}

In line with the problems of the study, the objectives are to: find out the types of impoliteness strategies that expressed by the participants in Jakarta Lawyers Club Talk Show.discover types of attacks are appeared in Jakarta Lawyers Club Talk Show.describe how the the participants respond to the attack in Jakarta Lawyers Club Talk Show.

\section{THEORETICAL REVIEW}

\subsection{The Concept of Politeness and Impoliteness}

\subsubsection{The Concept of Politeness}

Politeness is described as a social norm, or a set of prescriptive social rules. Many linguists have aimed to research politeness, including Brown \& Levinson (1987), who developed 'face theory' based on the principles of our desire to be liked and not to be imposed upon. It is first important to understand the concept of 'face'. The concept of' face' is at the core of Brown \& Levinson's (1987) theory to politeness. Face is defined as the public self-image every adult portrays, which must be attended to in interaction. There are two aspects of face namely positive and negative. Positive face is the desire to be appreciated and liked. Negative face is the desire to have freedom and not to be imposed upon. Politeness is defined as using communicative strategies to create and maintain social harmony. This can be done in various ways namely 1) being contextually appropriate, 2) following 


\section{Jurnal Ecobisma Vol. 4 No. 2 Juni 2017}

social and cultural norms, and 3) being socially positive by addressing face needs.Politeness are determined by contextual factors such as 1) power relations between speaker and listener, 2) Social distance between speaker and listener, and 3) how great the threat of the face threatening act is.

\subsubsection{The Concept of Impoliteness}


The concept of impoliteness is the opposite of politeness. When one act politely, he is trying to get along with other people and try to ensure that the communication goes on smoothly. If for some reason one wants to be impolite towards other people he is deliberately attacking others with his speech or as Culpeper (1996:350) says, we want to create a social interruption. According to Wardaugh (1992:274-275), when we act impolitely we are breaking the rules of politeness and if there were no rules of politeness we could not break them, that is, be impolite. Wardaugh (1992:275) states that impoliteness depends on the existence of standards, or norms, of politeness.

Herman (1995:240) points out that it would not be necessary to have rules of politeness, if there were not a danger of a social conflict. The rules of politeness are needed to neutralize impoliteness. Furthermore, the conceptualization of impoliteness adds perplexity to numerous researchers. This study borrows a revised definition offered by Culpeper (2005:38) stating that impoliteness comes about when: (1) the speaker communicates face-attack intentionally, or (2) the hearer perceives and/orconstructs behavior as intentionally face-attacking, or a combination of (1) and(2). It is held that impoliteness ought to integrate the speaker's intention as well as the hearer's understanding into consideration.

\subsection{Culpeper's (1996) Impoliteness Theory}

Culpeper (1996) questions if we even can talk about inherent politeness or impoliteness. Even though he talks about impoliteness, he relies a lot on politeness theorists such as Brown and Levinson, Leech, Fraser and Nolan. He points out that for example Leech (1983) has claimed in his theory that some illocution are inherently polite and some are impolite. However, Culpeper (1996) considers the role of context to be most central for interpreting utterances as inherently polite or impolite. Depending on the context, impolite acts can be understood as polite or polite acts as impolite. Culpeper (1996) takes picking one's nose as an example where it is difficult to find a polite way to ask the person to stop. An inherently impolite act is offensive and it cannot be used in politeness work because it harms the other's positive face in any case.

Culpeper, Bousfield \& Wichmann (2003) emphasize that the most important difference between politeness and impoliteness is speaker's intention and if he or she is going to support the hearer's face or attack against it. They consider the types of action that might lead to damaging of one's face. Firstly, the speaker might intentionally insult the hearer openly by acting maliciously and spitefully. Secondly, impoliteness might be an unplanned but anticipated by-product of action, in other words, an incidental offence. Thirdly, the speaker might act innocently or appear to do so because the offence seems to be unintended and unwitting. This kind of incident can be called 'faux pas' in French or a 'boner', which means an embarrassing mistake. Culpeper et al. (2003) also agree that impoliteness is very much dependent on context.

According to Culpeper (1996) mock impoliteness appears only on the surface level of utterances since these kinds of utterances are not meant to cause offence. Mock impoliteness is used to promote intimacy and it is common between close friends. It is also safer to use mock impoliteness among friends since it is more likely understood correctly then. Successful mock impoliteness is understood to be untrue but if it is taken as true, people will get offended. For example, if a person calls his or 
her friend a bastard in a gentle tone of voice and smiles at the same time it is most likely that the person does not mean it literally.

Culpeper (1996) takes a closer look at the circumstances when one is impolite. It is relevant whether the relationship between speakers is equal or unequal. When we think of equal relationships, the situations where impoliteness occurs are more complex. In close relationships, there is more impoliteness than between strangers. For example, spouses know each other so well that they know each other's soft spots for attacks and they also know howtheir partner is going to react when they get offended and how they can be appeased. The concern for face is also minor in close relationships than in relationships where persons do not like each other or one of the participants is more powerful. One notable characteristic of impoliteness in equal relationships is its tendency to increase. One verbal attack can easily lead to a counter-attack and in the end even to physical attacking even though mocking might have started as harmless. In some situations, the participants are in an unequal relationship and the motivation to cooperate is reduced.

Culpeper (1996) notes that the person who has more power in the situation can be more impolite than the "weaker" person can. The more powerful participant can use impoliteness to reduce the other participant's ability to retaliate and to threaten with retaliation if he or she acts impolitely. For example in courtroom situations, the relationship between the witness and the barrister is unequal. The barrister can be very impolite and try to make the witness lose his or her temper in front of a jury. Sometimes there can be a conflict of interests between participants and then it is not necessary to try to maintain each other's faces. A participant could have a particular interest to attack the other's face, for example, in a courtroom or in sport contests where only one person can win.

\subsection{Impoliteness Strategies}

Culpeper (1996) has described impoliteness as the parasite of politeness and that is why he has formed his impoliteness strategies in relation to Brown \& Levinson's politeness theory from the version published in 1987. Each of Brown and Levinson's superstrategies of politeness (bald on record, positive politeness, negative politeness, off-record and withholding the FTA) has its opposite impoliteness super strategy. These super strategies are not meant to support but to attack the other person's face.

\subsubsection{Bald on Record Impoliteness}

Bald on records impoliteness is performed in a direct, clear, unambiguous and concise way and the speaker's intention is to attack the hearer's face. A revised version of this strategy in Culpeper et al. (2003) takes into consideration that in this case there is a lot of face at stake and the speaker's intention is to attack the hearer's face or where the speaker does not have the power to (safely) utter an impolite utterance.

\subsubsection{Positive Impoliteness}

Positive Impoliteness is a strategy directed to attack the hearer's positive face. It is the opposite of Brown \& Levinson's theory (1987) of positiveface as "the want of every member that his wants be 
desirable to at least some others executors", or alternately, "the positive consistent selfimage or'personality' (crucially including the desire that this self-image be appreciated and approved of) claimed by interactants". . Brown (1997) characterized positive face by desires to be liked, admired, ratified, and related to positively, noting that onewould threaten positive face by ignoring someone Possible positive impolitenessoutputs: 1) ignore, snub the other, 2) exclude the other from an activity, 3) disassociate from the other, 4) be disinterested, unconcerned, unsympathetic, 5) use inappropriate identity markers, 6) use obscure or secretive language, 7) seek disagreement, 8) make other feel uncomfortable, 9) use taboo words, and 10) call other names.

\subsubsection{Negative Impoliteness}

Negative impoliteness is a strategy used to attack the hearer's negative face. It is also the opposite of Brown \& Levinson's theory (1987) of negative facewhich was defined as "the want of every 'competent adult member' that his actions be unimpeded by others", or "the basic claim to territories, personal preserves, rights to non-distraction--i.e. the freedom of action and freedom from imposition". Negative face is the desire not to be imposed upon, noting that negative face could be impinged upon by imposing on someone. The possibleoutput strategies are: 1) frighten, 2) condescend, scorn or ridicule, 3) invade the other's space, 4) explicitly associate the other with a negative aspect, 5) put the other's indebtedness on record. Culpeper et al. (2003) add another strategy into this category, which is hindering or blocking the other physically or linguistically.

\subsubsection{Sarcasm}

Sarcasm or mock politeness is performed with the use of politeness strategies that are obviously insincere, and thus remain surface realizations. Culpeper's (1996) understanding of sarcasm is close to Leech's (1983) conception of irony. This is of course the opposite of Brown \& Levinson's (1987) social harmony that is achieved through off-record politeness. One more point to add is that 'sarcasm' (mock politeness for social disharmony) is clearly the opposite of 'banter' (mock impoliteness for social harmony).

\subsubsection{Withhold Politeness}

Withhold politeness (Keep silent or fail to act where politeness work is expected) Culpeper (1996: $357)$ notes that impoliteness may be realised through, "[...] the absence of politeness work where it would be expected." Culpeper (2005: 42) gives the example that "failing to thank someone for a present may be taken as deliberate impoliteness." Culpeper (1996) further notes that Brown \& Levinson (1987) would appear to agree with the face-threatening aspects and implications surrounding the withholding of politeness when they claim:

politeness has to be communicated, and the absence of communicated politeness may, ceteris paribus, be taken as the absence of a polite attitude. (Brown \& Levinson, 1987: 5)

There are other important means by which impoliteness can be transmitted.The structure of conversation itself is sensitive to violations. Brown \& Levinson (1987) point out that turn-taking violations they are: interruption, ignoring selection of other speakers, not responding to prior turn are all Face Threatening Acts inthemselves, as are opening and closing procedures. 


\subsection{Types of Attacks}

Culpeper (2005) moves away from Brown \& Levinson (1987) in terms of replacing the negative/positive dichotomy but he does not explicitly revise his model in terms of SpencerOatey's (2002) concept of 'rapport management'. The reason behind this is that a single strategy may represent attacks on more than one of the two components of rapport management: face and social rights. Accordingly, Culpeper (2005) proposes the following attacks (Cashman, 2006: 228), though he does not explicitly carry out this re-mapping task (Cashman, 2006: 223), they are : 1) attacks on quality face, 2) attacks on social identity face, 3) attacks on equity rights, and 4) attacks on association rights.

Strategies to attack all the above aspects of face are the same as in Culpeper (1996). Culpeper et al. (2003:1563) map out the strategies available to a hearer and as shown in Table 2.1. Table 2.1 Types of Attacks

\begin{tabular}{|l|l|l|}
\hline Attacks on & Definition of desire/belief & Impoliteness strategies \\
\hline Quality face & $\begin{array}{l}\text { Desire to be evaluated } \\
\text { positively in terms of } \\
\text { personal qualities }\end{array}$ & $\begin{array}{l}\text { Attack the other's } \\
\text { appearance; attack the } \\
\text { other's ability/work. }\end{array}$ \\
\hline Social identity face & $\begin{array}{l}\text { Desire for acknowledgment } \\
\text { of our social identities or roles }\end{array}$ & $\begin{array}{l}\text { Condescend, scorn or } \\
\text { ridicule }\end{array}$ \\
\hline Equity rights & $\begin{array}{l}\text { Belief that we are entitled to } \\
\text { be treated fairly by others }\end{array}$ & $\begin{array}{l}\text { Frighten/threaten hinder } \\
\text { or block the other } \\
\text { physically or } \\
\text { linguistically, challenge } \\
\text { the other or impose the } \\
\text { other }\end{array}$ \\
\hline Association rights & $\begin{array}{l}\text { Belief that we are entitled } \\
\text { to associate with others in } \\
\text { accordance with the type of } \\
\text { relationship }\end{array}$ & $\begin{array}{l}\text { Ignore or snub the } \\
\text { other, disassociate from } \\
\text { the other }\end{array}$ \\
\hline
\end{tabular}

\subsection{Responding to Impoliteness}

After an occurrence of impoliteness, an interlocutor may or may not respond. A response may accept the impoliteness or counter it and the counter may be defensive or offensive. Offensive strategies are intended to match or escalate while defensive strategies include direct contradiction, abrogation, opt out on record, insincere agreement and ignore the attack. In short, responding to impoliteness can be 
done in one of the following ways namely: 1) not responding, 2) accepting impoliteness, 3) countering defensively, and 4) countering offensivelyChoosing not to respond may signal any number of phenomena, or intended participant aims, within a conversational exchange. For example, defending one's own face is one such possible reason for Staying Silent in the face of an impolite attack. Other reasons include being offensive, that is, refusing to speak when an expectation to speak exists. Other reasons include the participant not hearing the content of the utterance of one's interlocutor, accepting the Face Threatening Act (FTA) or simply not having understood the content of the utterance of one's interlocutor, among others. Staying Silent may indicate cognitive thinking time in shaping how one wants to respond. It may even indicate that the individual who is Staying Silent is simply 'struck dumb' or 'lost for words' given their interlocutor's utterance turn. It may even indicate that the individual Staying Silent simply hasn't got anything to say on the subject. Indeed, there are as many reasons to Stay Silent as there are contexts in which conversation can take place.

In accepting the face attack, the recipient may, for instance, assume responsibility for the impoliteness act being issued in the first place or they may agree with the impolite assessment contained within the exacerbated FTA. Thus, repeated, strong and personalized complaints might be met with an apology, and similarly a criticism may be met with an agreement. Note that this option involves increased face damage to the responder. It needs to be noted here that even Staying Silent, as discussed above, may well be an example of an individual accepting the face attack of the exacerbated, impolite, FTA. The alternative option, to counter the face attack, involves a set of strategies that can be considered in terms of whether they are offensive or defensive.

Counter strategies can be usefully classified into two, those offensive strategies which primarily counter face attack with face attack and those defensive strategies which primarily defend one's own face. These strategy groups are not mutually exclusive: defensive strategies may, intentionally or incidentally, also be offensive which damage an interactant's face in the process of saving one's own. In opting to counter a perceived, antecedent, FTA, participants may opt for an offensive or a defensive stance.

How one responds can lead to a 'pairing' effect. An impolite offence may be met with an impolite defense as a counter, to provide an offensive-defensive (OFF-DEF) pairing. Conversely, an impolite offence may be met with an impolite offence as a counter, to provide an offensive-offensive (OFF$\mathrm{OFF}$ ) pairing. The OFF-OFF pairing, as the name suggests, involves offensive strategies primarily countering face attack with face attack; this is the pattern referred to by Harris et al. (1986). Such offensive counter strategies are, of course, the impoliteness strategies of researchers like Culpeper (1996) or Lachenicht (1980).

\subsection{The Concept of Discourse Community}

A "discourse community" is a group of people who share knowledge of a particular topic, similar backgrounds and experiences, values, and common ways of communicating. Examples of academic discourse communities which include mathematicians, lawyers, engineers, biologists, sociologists, historians, etc.

Discourse community has been appropriated by the social 'perspectivists' for their variously applied purposes in writing research. Discourse operates within conventions defined by communities, be they 
academic disciplines or social groups. The idea of discourse communities: the center of a set of ideas rather than the sign of a settled notion. Only recently have compositional studies begun to investigate communities to writers and readers, though the terminology seems to be changing to 'discourse communities' in order to signal the focus on the written rather than the spoken.

JLC Talk show is an example of discourse community. It is designed as a formal Talk Show which its topics of discussion are politics, law, economy, education and others. The participants are lawyers, advocates, corruption watch, court constitution, representatives of political parties, elements of the police, prosecutors and other related elements including university students. The genre of JLC Talk Show is discussion which consists of a generic discussion of issue, pro and con arguments or arguments of various sides, and ends with conclusions and suggestions.

There are the six criteria of discourse community namely 1) common goals,participatory mechanisms, 3) information exchange, 4) community specific genres, 5) a highly specialized terminology, and 6) a high general level of expertise. On the other hand, the distance between members geographically, ethnically and socially presumably means that they do not form a speech community.

\subsection{Conversational Analysis}

Conversation analysis (CA) is an approach to the study of social interaction, embracing both verbal and non-verbal conduct, in situations of everyday life. As its name implies, CA began with a focus on casual conversation, but its methods were subsequently adapted to embrace more task- and institution-centered interactions, such as those occurring in doctors' offices, courts, law enforcement, helplines, educational settings, and the mass media. As a consequence, the term 'conversation analysis' has become something of a misnomer, but it has continued as a term for a distinctive and successful approach to the analysis of social interaction.Today CA is an established method used in sociology, anthropology, linguistics, speech-communication and psychology. It is particularly influential in interactional sociolinguistics, discourse analysis and discursive psychology. It is distinct from discourse analysis in focus and method namely 1) Its focus is squarely on processes involved in social interaction and does not include written texts or larger sociocultural phenomena (for example, 'discourses' in the Foucauldian sense), and 2) Its method, following Garfinkel and Goffman's initiatives, is aimed at determining the methods and resources that the interactional participants use and rely on to produce interactional contributionsand make sense of the contributions of others. Thus $\mathrm{CA}$ is neither designed for, nor aimed at, examining the production of interaction from a perspective that isexternal to the participants' own reasoning and understanding about their circumstances and communication. Rather the aim is to model the resources and methods by which those understandings are produced.CA seeks to describe conversation in a way that builds upon the way it is taken up by the people who are participating in it. It does this by paying attention to the way each utterance displays an interpretation of the previous utterance, and by paying particular attention to hitches, misunderstandings, and repairs:

"The methodology employed in CA requires evidence not only that some aspect of conversation can be viewed in the way suggested, but that it actually is so conceived by the participants producing it. That is, what conversation analysts are trying to model are the procedures and expectations actually 
employed by participants in producing and understanding conversation.... it may be started with the problem ofdemonstrating that some conversational organization is actually oriented to (i.e. implicitly recognized) by participants, rather than being an artifact of analysis. One key source of verification here is what happens when some hitch occurs -- i.e. when the hypothesized organization does not operate in the predicted way -- since then participants (like the analyst) should address themselves to the problem thus produced. Specifically, it may be expected them either to try to repair the hitch, or alternatively, to draw strong inferences of a quite specific kind from the absence of the expected behavior, and to act accordingly" (Levinson: 319)

For example, consider the following exchange between student (S) and teacher (T):1 S: So I was wondering would you be in your office after class this week?(2.0)

S: Probably not

T: Hmm no

Here the two-second pause after the students question -- a hitch in the conversation -- is interpreted as a negative answer to the question. Although a silence has no features on its own, conversational significance is attributed to it on the basis of the expectations that arise from its location in the surrounding talk. Below the three main kinds of interpretation of silence.

"A fundamental methodological point can be made with respect to [this example], and indeed most examples of conversation. Conversation, as opposed to monologue, offers the analyst an invaluable analytical resource: as each turn is responded to by a second, we find displayed in that second an analysis of the first by its recipient. Such an analysis is thusprovided by participants not only for each other but for analysts too" (Levinson, p. 321).

When we are trying to understand a particular utterance or conversational action it is important to consider where and how that action is located in a sequence of other conversational actions. When people speak in an ongoing conversation they do so in the light of what has just been said, and in anticipation of what might take place in the future. They "design" or "construct" their own speech, and understand the talk of other people, accordingly. They also shape their utterances to take account of the identity of the speakers and what their interests are. The meaning of an utterance -- the way it is interpreted, and the way it was designed -- depends, then, on its context, both verbal and nonverbal. This construction of utterances is called recipient design.

"This ongoing judgment of each utterance against those immediately adjacent to it provides participants with a continually updated (and, if need be, corrected) understanding of the conversation" (Nofsinger, p. 66). Every person involved in the conversation has their own interpretation of what is going on, but although these interpretations are subjective in the sense that everybody has their own, they are intersubjective in the sense that every person treats the adjacent utterances in similar ways. People share a understanding of the "game" they are engaged in, and its "rules." 2.8 TV Talk Show Timberg (2002:5) states that Talk Show program has principles or rules. The first principle, the event was hosted by a host helped the team responsible for the materials, direction, and shape events to be displayed. From this point the host is seen as a marketing label, trademark, that has a value of selling. The second principle is to contain the conversation containing the message. The third principle, the talk show is a competent product or commodity to another product. The fourth, a talk show is an integrated industrial activities involving a variety of professions, ranging from an event procedure, 
script writers, director of event, makeup artist and hair and part marketing. A Talk Show on television or radio program where the audience came together to discuss a variety of topics presented by a host. Another notion about Talk Show is a program that combines talk and show and event materials such as conversations or structured conversation structure (Rose, 1985). Since the material event is designed in such a way, for example on the theme that would be submitted, when, how the mode of delivery.

In Indonesian media, the Ministry of Information and Communication observes on some news, editorials and Talk Shows on several television programs and other media which still contain provocative and undemocratic language. If this is not acceptable to the people involved with the reported problem, of course, the news will cause irritation and may be causing anxiety and even social unrest.

The genre of the news on TV is recount with the generic structure: orientation and sequence of events. This genre is in conformity with the newsbecause the function of news is to tell or recall the past events. In general, the findings in the genre of recount is supported by a good external relations conjunction of time, continuative and metaphor. According to communication experts, genre reconstruction is appropriate to use because it embodies reconstruction genre news functions as a conduit of information about the past event.

Meanwhile, for the editorials and talk show are usually current affairs which is debated or interviewed panel Haarman (2001), use the genre discussion. The structure consists of a generic discussion of the issue, pro and con arguments or arguments of various sides, and ends with conclusions and suggestions. The genre of this discussion is in conformity with the purpose of the editorial and a talk show. This is due to the genre's discussions provide opportunities for resource persons in the editorials and talk shows is free to disagree and to see the problem from the other side to gain a more holistic conclusions and recommendation. So the experts also agreed on the use of communication genre this discussion on editorial programs and talk show on Indonesian TV media.

\subsection{Jakarta Lawyers Club (JLC) Talk Show}

Since 19 October 2012, Jakarta Lawyers Club Talk Show was changed to Indonesia Lawyers Club Talk Show. "Indonesia Lawyers Club" is a Talk Show program or a program that presents a conversation among the host, Karni Ilyas, with various resource persons coming from different backgrounds. Topics raised in general are related to political or legal issues that become the prime highlight in the community, with a particular focus on the discussion of the problem through the eyes of law practitioners in Indonesia. In addition, to a special guest speaker, there is also a process of exchange of ideas among the members of Jakarta Lawyers Club which is also the audience in the program, in addition to the audience from the floor. The general objective of this program, as quoted from the site TV One (www.tvonenews.tv/programs/ indonesia_lawyers_club, 2012), is a study forum of law for the viewers. The program Jakarta Lawyers Club airs every Tuesday, from 19:30 to 22:30 pm. TV One shows a re-run episode that played on Tuesday on Sunday in the same week, from 19:00 to $22: 00 \mathrm{pm}$. 


\section{RESEARCH METHOD}

\subsection{Research Design}

This study was a descriptive qualitative research design because the answers of the problems in this study were answered by giving explanation or describing in detail the impoliteness strategies of the utterances in JLC Talk Show. According to Bogdan \& Biklen (1992: 52), the design used in the research refers to the researcher's plan of how to proceed. Design decisions are made throughout the study - at the end as well as the beginning. Further, a qualitative research has five features, namely having natural setting and making the researcher as the key instrument, using descriptive words, concerning withprocess rather than simply with outcomes or products, analyzing data inductively, and having meaning as the essential concern.

This research design was used to fulfill the criteria of descriptive adequacy and explanatory adequacy based on Culpeper's (1996) theory which concentrated on the impoliteness strategies by collecting the data, transcribing the utterances used by the participants in the video of JLC Talk Show, identifying and categorizing the types of impoliteness strategies, types of attacks and how the impolite attacks responded by the participants in JLC Talk Show, making pattern and concluding of the impoliteness strategies, types of attack and how the impolite attacks responded by the participants in JLC Talk Show.

\subsection{The Source of Data}

The source of data in this study was the participants' utterances in JLC Talk Show in 2012 from the topics of the Talk Show namely "Badai DemokratMenerjang Kemana - Mana", "Anas Siap Digantung di Monas" and "Dibalik Bungkamnya Nazaruddin".

\subsection{The Technique of Data Collection}

The data were taken from the utterances of participants in JLC Talk Show. They were taken from videos of "Badai Demokrat Menerjang Kemana-Mana”, "Anas Siap Digantung di Monas and "Dibalik Bungkamnya Nazaruddin". Theutterances were transcribed, identified and selected which were considered as the impolite utterances according to Culpeper's (1996) strategies of impoliteness.

\subsection{The Instrument of Data Collection}

Instrument of data collection is a tool or equipment used in collecting the data. In collecting the data, the instrument of the study was observation. The researcher is the key of instruments who collects and observes the available data video in the internet.

\subsection{The Techniques of Data Analysis}

The data were analyzed by applying Miles \& Huberman's (1987) analysis model which consists of three steps namely 1) data reduction, 2) data display, andconclusion drawing or verification. The procedures in analyzing the data were:

(a) Selecting the data which were relevant to the research problem, identifying the data into the category. (b) Displaying some matrices which consist of some data from the utterances in different 
topics (c) Deciding what the data means or finding the pattern or regularities after reading the matrices or display.

\subsection{The Trustworthiness of the Study}

In qualitative research, the data should be auditable through checking that the interpretations are credible, transferable, dependable and confirmable. These are called as the trustworthiness. To fulfill these requirements, the study was conducted by four of them as follows.

\subsubsection{Credibility}

To make this research was credible, triangulation technique was used to verify the data with triangulation of data source and method. Triangulation of data source was done by taking data from a variety of time and topics. Triangulation of method was done by observing JLC Talk Show in different topics persistently and prolonged engagement with the use of instruments for more accurate data collected as video of JLC Talk Show and internet.

\subsubsection{Transferability}

The transferability of this research was achieved by giving the adequacy description of the research process and finding. The description which was called sending contexts to help the readers to see whether the results could be transferred to other different settings.

\subsubsection{Dependability}

To make sure that the findings were dependable deliberately checking and jotting down the process and result of the study was done. This process was called audit trail. In this requirement of trustworthiness, deliberately jotting down of the study was done through observation.

\subsubsection{Confirmability}

To make the research was confirmable, an audit trail was made which consists of raw data, reduced data and reconstructed data. In addition, some codes and appendices were also made so that the readers could easily understand the data.

\section{DATA ANALYSIS, FINDINGS AND DISCUSSIONS}

\subsection{Data Analysis}

The data in this study were the transcriptions of the participants' utterances in JLC Talk Show (see Appendices I, II \& III). The data in this study were analyzed by applying Miles \& Huberman's (1984) analysis model namely 1) data reduction, 2) data display, and 3) verification or conclusion drawing. The data display in this chapter were reduced based on Culpeper's (1996) theory. The data verification of this study presented as the findings at the end of this chapter.

\subsubsection{Types of Impoliteness Strategies}

There are four types of impoliteness strategies expressed by the participants in JLC Talk Show namely 1) Bald on Records Impoliteness, 2) Positive Impoliteness, 3) Negative Impoliteness, and 4) 
Sarcasm. Theorically, Culpeper (1996) categorizes that there are five strategies of impoliteness namely

Bald on Record Impoliteness, 2) Positive Impoliteness, 3) Negative impoliteness, 4) Sarcasm, and 5) Withhold Politeness.

\subsubsection{Bald On Record Impoliteness (BRI)}

There are fifteen expressions of Bald on Record Impoliteness expressed in JLC Talk Show (see Appendix IV). Culpeper et al. (2003) takes into consideration that in Bald on Records Impoliteness there is a lot of face at stake and the speaker's intention is to attack the hearer's face. Impoliteness work where the speaker does not try to save the hearer's face but insults them very clearly. It can be found as in the following data.

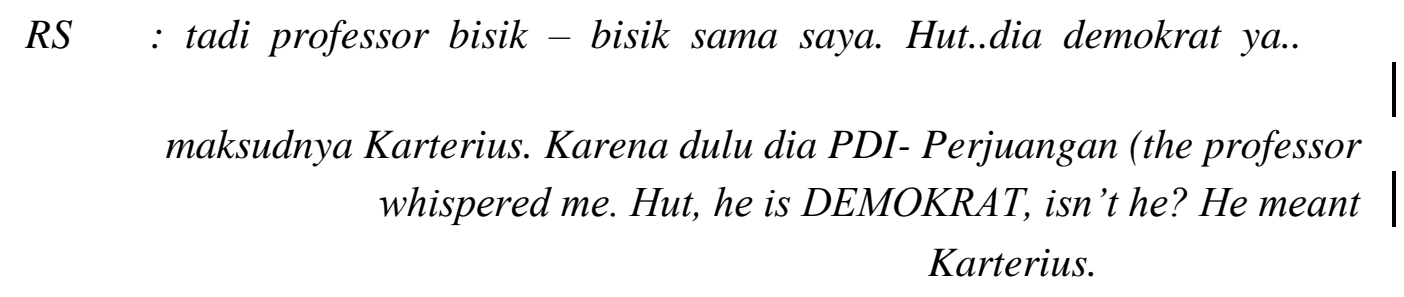

Because he was in PDI-Perjuangan formerly)

(BDMK/AI/P66/L103/Note :The code which ends in data 1, namely (BDMK/AI/ P66/ L103) is meant to be a means of leading the reader to retrace the complete, natural transcript where

the data 1 is quoted form the abbreviation of BDMK: Badai Demokrat Menerjang Kemanamana (the topic of JLC Talk Show); AI: Appendix I, P: Page; L: Line.

The data above shows that RS interferes in KS personal life by accusing that KS had ever joined a party namely PDI-P instead of telling his respond to the former speaker (KS) about the problem in their party namely Demokrat. Here, RS insults the speaker very clearly. It can be concluded by the tone of his voice and his facial expression. He said "Hut..dia demokrat ya..maksudnya karterius. Karena dulu diaPDI- Perjuangan." with low tone of voice and with his facial expression whichmeans insulting KS.

\subsubsection{Positive Impoliteness (PI)}

Positive impoliteness involves the use of strategies deployed to damage the hearer's positive face wants. There are eleven expressions of positive impoliteness expressed in JLC Talk Show (see appendix IV). Culpeper (1996) gives a list of examples about this strategy which include:1) Ignore, snub theother, 2) Exclude the other from an activity, 3) Disassociate from the other, 4) Be disinterested, unconcerned, unsympathetic, 5) Use inappropriate identity markers, 
Use obscure or secretive language, 7) Seek disagreement - select a sensitivetopic, 8) Make the other feel uncomfortable, 9) Use taboo words, 10) Call theother names - use derogatory nominations. Although Culpeper (1996) has listed,only three different sub-strategies expressed in JLC Talk Show (see Appendix IV), whereas there were ten positive impoliteness output strategies. The participants express three strategies namely 1) Ignore, snub the other, 2) Use taboo words, and

Use inappropriate identity markers. The first is originally one of a large set ofutterances which Culpeper (1996) viewed as attacking the intended recipient's want to be approved of. However, 'snubbing' an interlocutor not only shows disapproval, but also impedes the interactant from conversing with the snubber. It can be found in the following data.

RS : Okelah..up to you. Oke (tanpa melihat KS menggerakkan tangan tanda tidak peduli) (Okay, up to you. Okay (without seeing KS and move his hand which is meant that he snubs him)

(BDMK/A1/P66/L109)

RS continues his argument by snubbing KS and saying 'up to you. RS doesn't see KS when he speaks about him which means that RS doesn't care.

\subsubsection{Negative Impoliteness (NI)}

This strategy is designed to damage the addressee's negative face wants through the following: 1) Frighten, 2) Condescend, scorn or ridicule, 3) Invade the other's space, 4) Explicitly associate the other with a negative aspect, put the other's indebtedness on record. Although Culpeper (1996) has listed, only two different sub-strategies are expressed by the participants in JLC Talk Show (see Appendix IV), whereas there were four negative impoliteness output strategies. The participants used two strategies namely condescend, scorn or ridicule and explicitlyassociate the other with a negative aspect - personalize, use the pronouns 'I' and'you'.

However, this strategy is about relative power, belittling the other and not treating the other seriously (Culpeper, 1996). The following kind of instances found in the following data.

RS : ya..oke..up to you.Jadi begini kawan ini baru beberapa bulan. (so, thisfriend has just been some months in DEMOKRAT). saya ini oranghukum dia bukan orang hukum. (I'm a lawyer, he is not) Walaupun penasihat POLRI kayak abang. (although he is the advisor of Police ofRepublic Indonesia like you, brother)Tapi abang lawyer. (but you are a lawyer, brother)Yang ingin saya katakan begini bang..(what I'm going to say is..)Dan bung Amir saya ingatkan(and Mr.

Amir, I warn..)... saya tidak mau Bapak SBY yang menjadi korban. Dia the founding father dan dia ketua dewan Pembina dan Ketua dewan kehormatan...Kalo sayasebagai Kartorius saya malu. Baru berapa bulan dia di partai Demokrat. Bulan! ( If I were Kartorius I would be ashamed. He only has been inDemokrat for some months). Month! Saya ingin katakan sebelum dewan kehormatan memutuskan Nazaruddin dipecat kawan ini (pointing) 2 minggu sebelum keputusan dipecat kata dewan kehormatan. Apaurusannya dia datang. (what his business is...so he comes) Saya tahuyang bawa Amir Syamsudin.(I knew that Mr. Syamsudin took him) 


\section{(BDMK /A1/P67/L111)}

$\mathrm{RS}$ argues again that KS only has been some months in DEMOKRAT. He tells many times and finally shout out "Month!". His tone of voice is high when he talk about KS and AS but his tone of voice is lower when he talks about SBY. He always moves his right hand which means that he assert his statement RS condescend AS. Listen to RS comment, AS only takes a deep breath and laughs a little. AS looks like controlling his emotion. He doesn't give any responses although RS condescends him. 


\subsubsection{SARCASM (SA)}

Sarcasm, in Culpeper's (1996) terms, is the performance of politeness strategies that are obviously insincere, and thus remain surface realisations. There were four expressions of sarcasm expressed in JLC Talk Show (see Appendix IV) as in the following data.

$R S$ : ya..bukan bang.. apa ga melebar dari tadi. Kok giliran mereka boleh melebar. Kami tidak bang. Equal dong bang. Kami mohon keadilan. Bangdari tadi monyet lampung ini ngomong aku diam bang. (ya..nobrother. Does it not talk wider. Why in their turn they can talk widely. We don't brother.. equal please brother. We implore the fairness. Brother, of earlier this Lampung Monkey is talking $i$ just be silent.)

\section{(ASDM/A2/P75/L40)}

RS calls HP is a Lampung Monkey because he is really angry because HP has insuted his cadre. RS insults HP's appearance by saying 'Lampung Monkey ' loudly. The facial expression and the tone of RS voice show that he is really angry and he hates him. HP responds his statement by saying that $\mathrm{RS}$ is a comedian with high tone of voice and laughing.

The occurrences of impoliteness strategies expressed in JLC Talk Show are presented in Table 4.1.

Table 4.1 The Frequency of Impoliteness Strategies

\begin{tabular}{lll}
\hline Strategies & Number & Percentage \\
\hline BRI & 15 & $37.5 \%$ \\
\hline PI & 11 & $27.5 \%$ \\
\hline NI & 10 & $25.0 \%$ \\
\hline SA & 4 & $10.0 \%$ \\
\hline Total & 40 & $100 \%$ \\
\hline
\end{tabular}

The table shows that the highest frequency of impoliteness strategies expressed by the participants in JLC Talk Show is Bald on Records Impolitenessand the lowest frequency of impoliteness strategies expressed by the participants in JLC Talk Show is Sarcasm.

The comparison between theory and findings of what is found and what is not found in impoliteness strategies is presented in Table 4.2.

Table 4.2 Comparison Between Theory and Findings in Types of Impoliteness Strategies 


\begin{tabular}{|l|l|}
\hline Theory & Research Finding
\end{tabular}

\begin{tabular}{|l|l|}
\hline Types of Impoliteness Strategies & Types of Impoliteness Strategies \\
\hline Bald on Records Impoliteness & Bald on Records Impoliteness \\
\hline Positive Impoliteness & Positive Impoliteness \\
\hline Negative Impoliteness & Negative Impoliteness \\
\hline Sarcasm & Sarcasm \\
\hline Withhold Politeness & Withhold Politeness \\
\hline
\end{tabular}

Withhold politeness is not found in JLC Talk Show because of turn-taking violations, they are: interruption, ignoring selection of other speaker, and not responding to prior turn as opening and closing procedures. The types of impoliteness strategies expressed by the participants in JLC Talk Show are Bald on record Impoliteness, Positive Impoliteness, Negative Impoliteness, and Sarcasm.

\subsubsection{Types of Attacks}

There are two types of attacks appeared in JLC Talk Show (see Appendix IV) namely attacks on quality face and attacks on social identity face. Quality face is the dominant types of

attacks in JLC Talk Show. It can be concluded that theparticipants in JLC Talk Show mostly attacks one's desire to be evaluated positively in terms of personal qualities.

\subsubsection{Attacks on Quality Face (QF)}

Attacks on quality face are attacking the other's appearance, attacking the other's ability or work. The attacks on quality face can be shown in the following data.

RS : ada bendahara umum, ada wakil bendahara. Tupoksi bang. Udah gitu kalo ngomong apalagi ni kawan saya yang beberapa bulan baru masuk demokrat,. Saya ini ngomong terang benderang saja.

Gile dia bisa menilai TPF itu apatadi katanya, ha...illegal. Wah ini kawan. Kalo aku lempar handuk keluar dari partai demokrat. Malu. Merusak.He's crazy that can say 
from DEMOKRAT, ashamed. harmed)

BDMK(A1/ P68/L164)

RS attacks AS's quality face by stating that AS has joined democrat party for some months. RS insults AS by calling him crazy, ashamed and harmed the party. He points out AS with his point finger and googles his eyes.

The similar type of data can be found in the following data. A woman commented on Anas' statement on TV that he was ready to be hung on MONAS if he had corrupted even a rupiah in

Hambalang case. The woman attacked Anas's quality face by stating that Anas was not honest and make a supposition that Anas' face was the face of prophet but his brain was Abu Jahal's.

MRS : terimakasih. Sebenarnya kalo melihat Anas. Sebenarnya Anas itu bukan seperti jujur. Jadi mukanya muka nabi tapi otaknya Abu Jahal.(Thankyou. Actually if I see Anas. Actually Anas is not honest. His face is theface of prophet but his brain is Abu Jahal's brain.

ASDM (A2/ P73/L165)

4.1.2.2 Attacks on Social Identity Face (SIF) Attacks on social identity face is attacking one's desire for acknowledgment of his or her social identities or roles. The attacks on social identity face can be shown in the following data.

RS : ... Jadi begini kawan ini baru beberapa bulan.(so, this friend has justjoined for some months in DEMOKRAT).saya ini orang hukum diabukan orang hukum. (I'm a lawyer, he is not) Walaupun penasihat POLRI kayak abang.(although he is the adviser of Police of RepublicIndonesia like you, brother )Tapi abang lawyer...(but you are a lawyer, brother) Danbung Amir saya ingatkan... (and Mr. Amir, I warn..)... Bung Oce mengatakan kenapa putusan pemecatan dari DPP. Sayakatakan, ini ada saudara Kartorius Sinaga. Kalo saya sebagai Kartorius saya malu. Baru berapa bulan dia di partai democrat. Bulan! (If I were Kartorius I would be ashamed. He only has been in

DEMOKRAT for some months). Month! Saya ingin katakan sebelumdewan kehormatan memutuskan Nazaruddin dipecat kawan ini (pointing) 2 minggu sebelum keputusan dipecat kata dewan kehormatan. Apa urusannya dia datang. (what his business is...hecomes) Saya tahu yang bawa Amir Syamsudin. (I knew that Mr. Syamsudin took him)

\section{(BDMK/A1/P67L111)}

RS attacks AS's and KS' roles in Demokrat party by arguing that KS only has joined for some months in DEMOKRAT. He tells many times and finally shouts out "Month!". His tone of voice is high when he talk about KS and AS. He always moves his right hand which means that he asserts his statement. RS condescends AS. 
Theoretically, Culpeper et al. (2005) proposes types of attacks namely 1) attacks on quality face, 2) attacks on social identity face, 3) attacks on equity rights, and 4) attacks on association rights. In JLC Talk Show, there are two types of attacks appeared. The occurrences of types of attacks in JLC Talk Show are presented in Table 4.3.

Table 4.3 The Frequency of Types of Attacks

\begin{tabular}{lll}
\hline Attacks & Number & Percentage \\
\hline QF & 37 & $92.5 \%$ \\
\hline SIF & 3 & $7.5 \%$ \\
\hline
\end{tabular}




Total $\quad 40 \quad 100 \%$

The table shows that the highest frequency of attacks by the participants in JLC Talk Show is attacks on quality face and the lowest frequency of attacks is attacks on social identity face.

The comparison between theory and findings of what is found and what is not found in types of attacks presented in Table 4.4 .

Table 4.4 Comparison Between Theory and Findings in Types of Attacks

\begin{tabular}{|l|l|}
\hline Theory & Research Finding \\
\hline Types of Attack & Types of Attack \\
\hline Quality face & Quality face \\
\hline Social identity face & Social identity face \\
\hline Equity rights & Equity rights \\
\hline Association rights & Association rights \\
\hline
\end{tabular}

Attacks on equity rights and association rights are not found in JLC Talk Show. The types of attacks appeared in JLC Talk Show are attacks on quality face and social identity face.

\subsubsection{Responses to Impolite Attacks}

There are three ways of responses to the impoliteness expressed by the participants in JLC Talk Show namely 1) not responding, 2) countering defensively, and 3) countering offensively. Theorically, Culpeper (1996) categorizes that there are four types of responses to Impoliteness namely1) notresponding, 2) accepting impoliteness, 3) countering defensively, and 4) countering offensively. When the impoliteness occurs, an interlocutor may or may not respond. A response may accept the impoliteness or counter it defensively or offensively. 


\subsubsection{Not Responding (NR)}

Theoretically, Culpeper (1996) states that choosing not to respond the impolite attack may signal the defending one's own face, the expectation to be polite, the participant not hearing the content of the utterance of one's interlocutor, cognitive thinking time in shaping how one wants to respond, interlocutor's utterance turn and simply not having understood the content of the utterance of one's interlocutor. Not responding is the most dominant responses to the impolite attack among

participants in JLC Talk Show (see Appendix V). Not responding the impolite attack can be shown in the following data.

HP : Anak bininya ditelantarkan (His son and wife are neglected)

RS : Apalagi Ibu. Bu (And you madam, madam)ASDM (A2/ P75/L245,246)

HP insults RS by saying that RS has neglected his son and wife but RS still continue his argument to a woman because the woman insults the head of Demokrat party (Anas Urbaningrum).

\subsubsection{Countering Defensively (CD)}

Defensive strategies to respond the impolite attack include direct contradiction, abrogation, opt out on record, insincere agreement and ignore the attack. The defensive strategies can be found in the following data.

RS : tadi professor bisik - bisik ke saya. Hut..dia Demokrat ya.. maksudnya

Karterius. (pointing) Karena dulu dia PDI- Perjuangan (the professor

whispered me. Hut, he is Demokrat, isn't he? He meant Karterius.

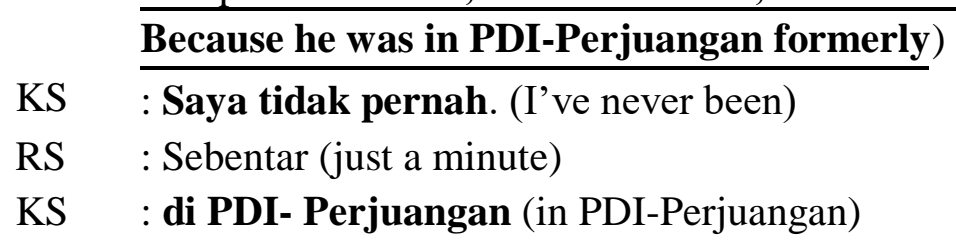

KS : Saya tidak pernah. (I've never been)

RS : Sebentar (just a minute)

KS : di PDI- Perjuangan (in PDI-Perjuangan)

BDMK(A1/ P66/L103)

KS responds to RS' statement that he has never been in Demokrat neither as a member nor as a legislative candidate. KS responds to RS statement directly without waiting for his turn to clarify. In the following data is also found the similar way of responding the impolite attack. 
: (Sambil berdiri) (Standing) Sebentar bang. Biar saya jawab. Ini saya dapat berita ini. Memang dia telepon tapi untuk mengatakan jangan kamu berbohong. Apakah kamu lagi mabok. Istrimu yang 4 itu aja urusin.

Wait brother. Let me answer. This i get the news. Certainly he called but forsaying ' don't lie'. Are you drunk. The four of your wifes that you shouldhandle.Itu mau yang dibicarakn tadi inilah. : (Menyela pembicaraan) (Interrupting) Tidak seperti itu. Tidak seperti itu. Tidak seperti itu. Demi Allah (duduk kemudian berdiri). Itu tidak seperti itu (duduk kembali) Dia telpon... Tapi kalau dikatakan istri saya3..4..istri saya 4. Istri saya 3 terus terang. Tetapi istri 3 itu sah. akur semuanya. Not like that. Not like that. Not like that. In god's name (standup). It's not like that. He called... But if it is said that my wives are 3..4..my wife is four. Honestly my wives are three. But the three wifes are legal. All are agreed.

ASDM (A2/ P71/L69)

$\mathrm{T}$ responds to $\mathrm{R}$ directly without waiting for his turn. $\mathrm{T}$ interrupts $\mathrm{R}$. He responds defensively by saying 'not like that' loudly. $T$ explains that he has three wives not four.

\subsubsection{Countering Offensively (CO)}

Offensive strategies are intended to match or escalate the impolite attack. The following data shows that HP attacks RS' quality face. HP insults RS very directly by saying about her son. RS insults HP directly by attacking HP's quality face. RS also insults him by interfering HP's personal life that HP was broken heart with Meriam Belina, his affair girl.

HP : Anak kamu gimana sekarang? Ga usah banyak ngomong deh lu.

(Howis your son now? You don't talk too much).

RS :eeh..eeh.. janganlah.udah diputuskan meriam belina jadi kau ha..patah hati sama meriam belina. Jangan gitu..ga baik. (eeh..eeh.. dont..you have been separated by Meriam Bellina so you haa..broken heart with Meriam Belina. Don't be like that. Not good)

\section{ASDM (A2/ P76/L285)}

RS insults RS directly by attacking HP's quality face. RS also insults him by interfering HP's personal life that HP is broken heart with Meriam Belina.

The similar type of data can be found in the following data. RS insults HP by saying that HP is an immoral person. HP looks angry and insults RS again by saying RS is an immoral person two times with high tone of voice.

RS : Kau yang diam. Inilah manusia yang tidak bermoral! (You shut up.

This is an immoral person!) HP : Kau yang tidak bermoral ! Kau yang tidak bermoral!( You are immoral! You are immoral!)

ASDM (A2/ P75/L214-216) 
The occurrences of the participants' responses to the impolite attacks in JLC Talk Show are presented in Table 4.5 .

Table 4.5 The Frequency of Responding to Impolite Attacks

\begin{tabular}{lll}
\hline Attacks & Number & Percentage \\
\hline $\mathrm{NR}$ & 21 & $52.5 \%$ \\
\hline $\mathrm{CD}$ & 13 & $32.5 \%$ \\
\hline $\mathrm{CO}$ & 6 & $15.0 \%$ \\
\hline Total & 40 & $100 \%$ \\
\hline
\end{tabular}

The table shows that the highest frequency of the participants' responses to the impolite attacks in JLC Talk Show is 'not responding' and the lowest frequency of the participants' responses to the impolite attacks in JLC Talk Show is 'countering offensively'.

The comparison between theory and findings of what is found and what is not found in the way of responding the impolite attacks presented in Table 4.6.

Table 4.6 Comparison Between Theory and Findings in Responding Impolite Attacks

\begin{tabular}{|l|l|}
\hline Theory & Research Finding \\
\hline Responses & Responses \\
\hline Not Responding & Not Responding \\
\hline Accepting Impoliteness & Accepting Impoliteness \\
\hline
\end{tabular}




\begin{tabular}{|l|l|}
\hline Countering Defensively & Countering Defensively \\
\hline Countering Offensively & Countering Offensively \\
\hline
\end{tabular}

Accepting Impoliteness was not found in JLC Talk Show. The way of responding the impoliteness are not responding, countering defensively and countering offensively.

\subsection{Findings}

After analyzing the data deliberately, the types of impoliteness strategies, types of attack, and how the responses to the impolite attacks, there are some findings found as the following.

\subsubsection{Types of Impoliteness Strategies}

The types of impoliteness strategies found in JLC Talk Show are four types of impoliteness strategies namely 1) Bald On Record Impoliteness, 2) Positive Impoliteness which consists of three substrategies : ignore or snubthe other, use inappropriate identity marker, and use taboo words, 3)Negative Impoliteness which consists of two sub- strategies: condescend,scorn, ridicule and explicitly associate the other with a negative aspect - personalize, use the pronouns 'I' and 'you', and 4) Sarcasm. In this case, Baldon Record Impoliteness is the dominant types of impoliteness strategies found by the researcher in JLC Talk Show. It is very interesting that particularly Bald on Record strategy is the most used against among lawyers or among members of the party. The lawyers or the members of the party want to emphasize his relative power over the other, Lawyers or the member of a party use impoliteness strategies to some extent in the Talk Show. Impoliteness is used to give support for the lawyers or the member of the party the relative power against their opponents and to emphasize their point of view in the Talk Show. It also indicates that one who expresses this strategy is a very direct person. Withhold politeness is not found in JLC Talk Show. It may because of turntaking violations, they are: interruption, ignoring selection of other speaker, and not responding to prior turn as opening and closing procedures.

\subsubsection{Types of Attacks}

There are two types of attacks found in JLC Talk Show namely attacks on quality face and attacks on social identity face. In this case, the dominant type of attacks is the attacks on quality face which attacks on one's appearance or one's ability or work. The attacks on quality face makes negative impact in terms of personal qualities it means that the participants in JLC attack the other participants personally. The participants can give their comments or their responses to the other participants directly and personally in the Talk Show.

\subsubsection{Responses to Impolite Attacks}


And for the responses to the impoliteness attacks, there are three ways of responses to impolite attacks. They are not responding, countering defensively and countering offensively. Choosing not to respond the impolite attacks may signal the defending one's own face, the expectation to be polite, the participant not hearing the content of the utterance of one's interlocutor, cognitive thinking time in shaping how one wants to respond, interlocutor's utterance turn and simply not having understood the content of the utterance of one's interlocutor.

\subsection{Discussion}

In the forty data which are transcribed in the data displayed, there are several cases of impoliteness strategies in each of them. It is not possible tocount their exact number because defining where one case of impoliteness starts and where it ends is extremely difficult. However, some rough observations can be made based on the data analysis.

Theorically, Culpeper (1996) categorizes that there are five strategies ofimpoliteness namely1) Bald on Record Impoliteness, 2) Positive Impoliteness, 3)Negative Impoliteness, 4) Sarcasm, and 5) Withhold politeness but there are four types of impoliteness strategies expressed by the participants in JLC Talk Show namely 1) Bald on Record Impoliteness, 2) Positive Impoliteness, 3) Negative Impoliteness, and 4) Sarcasm. Bald on Record Impoliteness strategies is the most frequent expressed by the participants in JLC Talk Show. The participants interferes the other paticipants' personal life by accusing and insulting clearly and directly. Hence with the culture of Indonesian which avoid talking directly in conveying the opinions and feelings. The tone of voice, facial expression and body language of the participants are also considered in analyzing the data because they describe the emotions of the participants. The reason why the participants in JLC Talk Show might use this strategy to a great extent is that the participants are very direct 
persons. They do not try to hide their true feelings and enjoy being rude to other people. They have no interest to please other people and no need to be likeable especially the participant who has been far longer or has more power in an institution, party and organization.

Positive Impoliteness strategies are much harder to find than Bald on Record Strategies. Especially in sub-strategies use taboo words. There were only a few instances of these in the interaction among the participants in JLC talk show such as

"stupid" and "see the case like a girl. Don't enter a half way". As was mentioned in the analysis, calling the other speaker comedian mouth overlaps with another sub-strategy of positive impoliteness, which is use inappropriateidentity marker. Allan \& Burridge (2006) have examined impoliteness throughtaboo language and these expressions clearly are dysphemisms, dispreferred language for a lawyer as an educated person. Among friends one could use these terms without being offensive, but in this context it is not suitable. Moreover, it should be noted that although Culpeper has listed ten different substrategies for positive impoliteness, in JLC only uses a few of them. The reason for this might be that some of these sub-strategies involve excluding or ignoring the other person somehow, and this is not really possible in the talk show interaction that they have turn to clarify.

Although Culpeper (1996) has listed ten Negative Impoliteness output strategies. The participants express two strategies those are condescend, scorn orridicule and explicitly associate the other with negative aspect-personalize, usethe pronouns 'I' and 'You'. Condescend is an effective way to make a point, especially when the ridiculer is one who has more knowledge, experience, higher level or position in a party or in an institution about the discussed matter than the hearer. Explicitly associate the other with negative aspect-personalize, use the pronoun 'I' and 'You' as in BDMK (A1/P68/L157) and ASDM (A2/P74/L206-are the disputes on TVOne which is broadcasted lively. The risk of live show is no censor so that what has happened can not be emended. Sinaga (2009) statesthat in Bataknese language, both characters Ruhut Sitompul (RS) and Hotman Paris (HP) are called Parbada by Bataknese people. Parbada means one who likes to make a disturbance or a quarrel. Usually, Bataknese people describe it as one who can not be reconciled or one who likes to make a disturbance. Boni (2014) states that the inconsequential Ruhut's utterances be a type of thinking system that he called as Ruhutisme. Someone who acts like Ruhut also be referred to as Ruhutis. Ruhutisme is a chaotic system of thinking and inconsequential. Which is not based on the reasoning syllogistic and based on the accurate data. It is tendentious to attack the speaker personally and even attack the other person irrationally with derogatory racial and ethnic identity.

Withhold Politeness is not found in any of the extracts because of turn - taking violations, they are: interruption, ignoring selection of the speaker and not responding to prior turn as opening and closing procedures. In JLC Talk Show, there's no expectation of politeness, it cannot be impolitely withheld. However, sarcasm is found in the data. 
Insulting, prohibiting, arguing and using a particular annoyed and angry tone of voice, googling eyes which can easily spot as the sarcasm.

There are two types of attacks found in JLC Talk Show namely attacks on quality face and attacks on social identity face. The attack on quality face is the dominant type of attacks in attacking on the participants' appearance or the participants' ability or work. It indicates that in JLC Talk Show, the participants are attacked in terms of personal quality. The attacks on equity rights and association right are not found in JLC Talk Show because JLC Talk Show is designed as an interactive dialogue which each participants has equal rights to convey his or her opinions or has

turn to convey or clarify his or her opinions. The participant in the Talk Show can not impose the other because the host of the Talk Show manage the interactive dialogue. The participants are also from variety of elements such as lawyers (HP, RS, and R), observer (TH), political member (T, KS, and AS).

Choosing not to respond the impolite attacks is the dominant way in responding the impolite attacks which signals the defending one's own face, the expectation to be polite, the participant not hearing the content of the utterance of one's interlocutor, cognitive thinking time in shaping how one wants to respond, interlocutor's utterance turn, simply not having understood the content of the utterance of one's interlocutor and dealing with the difficult people. Countering offensively is the lowest frequency because few of the interactants in the data are in the same social or power positions as their interlocutors. Accepting Impoliteness is not found in JLC Talk Show. Latinen (2012) states in her thesis that accepting a face attack was rather rare. Moreover, She thought that remaining silent was also a form of accepting a face attack, and thus it was rather difficult to separate these two.

For the reasons of 1) the concretization and formalization of citizens' rights in a fluid and changing world, people are having to discover, or rather create for themselves some concept of just what their rights are. Such a changing, non-solidified situation could easily contribute to a culture in which people are quick to complain and 2) changes in governance raise difficult questions concerning "power", "rights" and "ethics", studying how and under what conditions impoliteness is generated is an important and worthy object of study. Such a study will also lead towards indicating how interactants deal with such impoliteness. It will, in effect, show how impoliteness may potentially be countered, controlled and managed.

\section{REFERENCES}

Bogdan, R. \& Biklen, S. 2010. Qualitative Research forEducation: An Introduction to Theory and Methods. Boston: Allyn and Bacon. 
Brown, H. D. 2007. Principles of Language Learning and Teaching: FifthEdition. New York: Pearson Education.

Brown, P. \& Levinson, S. 1978. Universals in Language Usage: PolitenessPhenomena. In E. N. Goody. Question and Politeness Strategies in Social Interaction, pp. 56311. Cambridge University Press.

Brown, G. \& Yule, G. 1983. Discourse Analysis. Cambridge: Cambridge University Press.

Bousfield, D. 2007. Beginnings, Middles and Ends: A biopsy of the dynamics of impolite exchanges. Journal of Pragmatics, 39 (12), 2185-2216.

Bousfield, D. 2008. Impoliteness in Struggle for Power in Bousfield, D \& Locher (eds.), M. Impoliteness in Language-Studies on its Interplay with Powerand Practice. Berlin: Mouton de Gruyter.

Culpeper, J. 1996. Towards An Anatomy of Impoliteness. Journal of Pragmatics, Volume 25, Issue 3, 349-367.

Culpeper, J., Bousfield, D., \& Wichmann, A. 2003. Impoliteness Revisited: With Special Reference to Dynamic and Prosodic Aspects. Journal ofPragmatics, 35, 1545-1579.

Culpeper, J. 2005. Impoliteness and Entertainment in the Television Quiz Show: The Weakest link. Journal of Politeness Research, 1, 35-72.

Culpeper, J. 2008. Reflections on Impoliteness, Relational Work and Power in Bousfield, D \& Locher (eds.), M. Impoliteness in Language-Studies onits Interplay with Power and Practice. Berlin: Mouton de Gruyter.

Fasold, R. 1990. The Sociolinguistics of Language. Oxford: Blackwell. 